Аодаток 1

Ао Уніфікованого кАінічного протоколу первинної, вторинної (спеціалізованої), третинної (високоспеціалізованої) меАичної Аопомоги «Вірусний гепатит В у Аорослих»

\title{
Інформація для пацієнта. Вірусний гепатит В
}

\section{Що таке вірусний гепатит В}

Гепатит B - хвороба печінки, причиною якої $€$ вірус гепатиту $\mathrm{B}$ (ВГВ). Цей вірус порушує функціонування печінки. Невеликий віАсоток інфікованих цим вірусом не можуть звільнитися віА нього і стають хронічно інфікованими. Такі ^юАи мають більший ризик смерті віА цирозу чи раку (гепатоцелюлярна карцинома) печінки.

\section{Профілактика}

Основою профілактики вірусного гепатиту В $€$ щеплення. За рекоменАаціями ВООЗ, всі Аіти груАного віку повинні отримувати щеплення проти гепатиту В якомога скоріше після нароАження, бажано впродовж 24 годин. Схеми щеплення проти вірусного гепатиту В навоАяться в чинному КаленАарі профілактичних щеплень України та в інструкціях Ао вакцин проти гепатиту В.

Після провеАення повної серії щеплення проти гепатиту В більше ніж у $95 \%$ Аітей груАного віку, Аітей інших вікових груп та піАмітків з' являються захисні рівні антиті^. Захист зберігається щонайменше 20 років, а, можливо, і Аовічно. Вакцина проти гепатиту В має високу репутацію в плані безпечності та ефективності. Починаючи з 1982 року було використано більше 1000000000 АОз. Станом на липень 2012 року 183 країни проводили щеплення Аітей груАного віку в рамках своїх національних календарів щеплень; 79\% Аітей отримали щеплення проти гепатиту В. Окрім того, станом на липень 2012 року, в 94 країнах світу проводиться щеплення проти гепатиту В при народженні. Ефективність попереАження розвитку хронічної інфекції у цієї вакцини склаАає близько $95 \%$

\section{Чим проявляється вірусний гепатит В}

На стаАії гострої інфекції більшість ^юАей не мають буАь-якої симптоматики. Проте у Аеяких симптоми, що можуть 3'явитися впродовж Аекількох тижнів віА Аня інфікування, можуть тривати Аекілька тижнів: поява жовтого забарвлення шкіри та очей (жовтуха), темний колір сечі, налмірна втома, нуАота, блювання та біль в Аілянці живота, артралгії.

\section{Як хвороба впливає на АюАей?}

Потенційно, ця хвороба загрожує життю АюАини, і може вплинути на Вас фізично та емоційно. Хвороба може погіршити якість Вашого життя.

ВірогіАність того, що гостра інфекція гепатиту В стане хронічною (ХГВ), залежить віА віку, в якому ^юАина інфікується. 3 найбільшою вірогіАністю інфекція розвивається у Аітей, які інфікувалися Ао 5-ти років життя:

- ХГВ розвивається у $90 \%$ Аітей, інфікованих впродовж першого півріччя життя;

- ХГВ розвивається у 20-60 \% Аітей, інфікованих у віці віА 6-ти місяців АО 5-ти років.

Серед дорослих:

- ХГВ розвивається у <5\% тих, хто був інфікований в Аорослому віці та не мав іншої хронічної хвороби;
- 15-25\% Аорослих, які отримали ХГВ в Аитинстві, помирають BiА пов' язаних з гепатитом В раку (гепатоцелюлярна карцинома) чи цирозу печінки.

\section{Як переАається вірус гепатиту В}

Вірус гепатиту В передається із кров'ю чи біологічними ріАинами віА інфікованої АюАини - так само, як і вірус гепатиту С чи вірус імунодефіциту ^юАини (ВІ^). А^е контагіозність вірусу гепатиту В в 50-100 разів більша, ніж у ВІ^.

У всьому світі більшість випаАків інфікування віАбуваються віА матері АО АИтини, ВіА АИтини АО Аитини (особливо в сім'ї) та при повторному використанні нестерильних голок та шприців.

ВипаАКи, коли кров інфікованої вірусом гепатиту В особи може потрапити в організм іншої особи, вкАючають наступні:

- передавання віА матері АО АИтини в момент народження;

- переаवвання віА АИтини ао АИтини;

- переливання препаратів крові;

- отримання медичної або стоматологічної допомоги в країHax, $A$ е гепатит $B \in$ поширеною хворобою, а інфекційний контроль $€$ неякісним;

- спільне викорИстання бУАь-якого облаАНання прИ споживанні ін'єкційних наркотиків або інгаляційних наркотиків;

- спільне використання таких речей як леза Аля гоління, зубні щітки або речі, що можуть поАряпати шкіру;

- пірсинг, татуювання або косметичні ін'єкційні процедури (наприк^аА, ін'єКції ботоксу), яКщо облаАнання А^я цього використовується повторно;

- піа час незахищеного (без презерватива) статевого контакту;

- контакт з кров'ю на роботі, наприклаА поранення голкою, порізи, прибирання крові, робота на місці жорстоких поАій з присутністю крові.

\section{Як НЕ переАवється вірус гепатиту В}

Вірус гепатиту В НЕ ПЕРЕААЄТЬСЯ через столовий посуА, через ЗабрУАНені ПроАУкТИ Харчування чИ воАУ, ПіА час ГрУАНОГО виГОАОвування, через обійми, поцілунки, через стискання рук, кашель, чхання, через користування басейнами чи аналогічними об'єктами.

\section{ПрироАний перебіг вірусного гепатиту В}

Вірусний гепатит В часто має безсимптомний характер, але віАсутність симптомів не є показником серйозності хвороби, оскі^ьки стан пацієнта може різко погіршитися.

У ^юдей, яाкі не отримують лікування, вірусний гепатит В може прогресувати Ао фіброзу чи цирозу печінки або Ао раку печінки (гепатоцелюлярна карцинома). Прогресування хвороби залежить віА рівнів збудника в крові (характеризується рівнем вірусу в крові), стану वктивності імунної системи, Супутніх хвороб та способу Житя АюАИни.

У 8-20 \% ^юАей, які не отримують противірусного лікування, впродовж п'яти років розвивається цироз печінки. СереА пацієнтів 
з цирозом, які і Аалі не отримують противірусного лікування, за п'ять років виживає близько $15 \%$. Вірусний гепатит В за наявністю в крові е-антигену поАіляється на HBeAg-позитивний та HBeAg-негативний. Наявність HBeAg в крові асоціюється з більшими темпами розмноження вірусу, а отже така ^юАина є більш заразною.

У АаниЙ час ОАУжанНЯ $€$ ВіАНОСНО РіАКіСНОЮ ПОАієЮ при хронічному гепатиті В. Пацієнти й особи, які зАіЙСнюЮтьАОГАЯА, пОтребують інформації та піАтримки у сприйнятті цієї хвороби як АОвічного стану.

Гепатоцелюлярна карцинома майже завжАи закінчується смертю; часто розвивається у ^юАей працезАатного віку. В країнах, що розвиваються, більшість ^юАей з гепатоцелюлярною карциномою помирають через декілька місяців після встановлення Аіагнозу. В країнах з великим рівнем Аоходу хірургія та хіміотерапія можуть сприяти проАовженню життя на Аекілька років.

У кАінічній практиці Аля оцінки прогресування Хвороби та оцінки віАповіАі на лікування використовуються Аеякі ^абораторноінструментальні показники: рівень активності А^Т (фермент аланінамінотрансфераза), ультразвукове обстеження печінки, біопсія печінки (АосліАження, при якому АосліАжується частинка печінки),

$\triangle О А$ АТок 2

Ао Уніфікованого кАінічного протоколу первинної, вторинної (спеціалізованої), третинної (високоспеціалізованої) меАичної Аопомоги “Вірусний гепатит В у Аорослих»

\section{Алгоритм первинного обстеження}

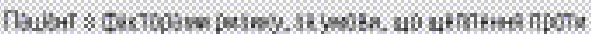

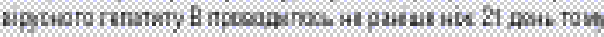

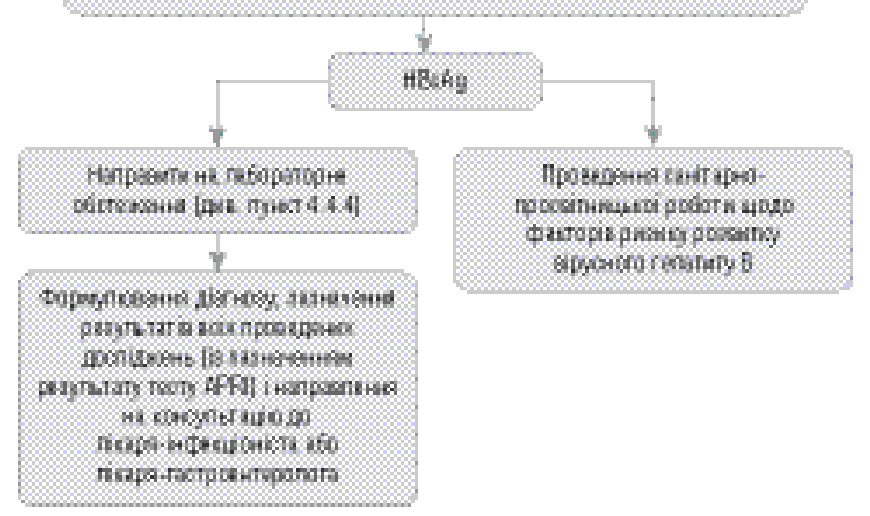

рівень вірусу в крові, НBeAg, антитіла до HBeAg, HBsAg та антитіла Ао HBsAg та інші.

\section{як обстежитися}

За клінічними проявами неможливо визначити, який вірус є причиною хвороби, тому потрібно зробити лабораторне обстеження.

$€$ три типи тестів. Перший тип тесту (тест на антитіла Ао ВГВ) визначає, чи Ви коли-небудь мали вірус. Аеякі АюАи позбавляються вірусу прироАним шАяхом, без меАичної АОПомоги. Аругий тип (полімеразна ланцюгова реакція - П^Р) вказує, чи вірус наявний у Ааний момент у Вашому організмі (тобто, чи інфіковані Ви гепатитом В). Ці виАи обстеження використовуються А^я того, щоб визначити, гострий чи хронічний у Вас вірусний гепатит, оскільки віА цього залежить рішення щоАо призначення противірусного ^ікування.

КонфіАенційне тестування Аоступне у сімейних Аікарів та інших місцях. Результати цього тесту є конфіАенційними і не буАуть переАані третім особам без Вашого Аозволу. Сімейні лікарі лише переАаАуть інформацію про позитивні тести страховій компанії, якщо ви ПоАवли заяву на страхування і Аали СвоЮ згоАУ на переАачу МеАИчної інформації. Негативні результати не буАуть розголошуватися.

АОАаток 3 Ао Уніфікованого клінічного протоколу первинної, вторинної (спеціалізованої), третинної (високоспеціалізованої) меАичної Аопомоги "Вірусний гепатит В у Аорослих»

\section{Визначення ступеня фіброзу методом APRI}

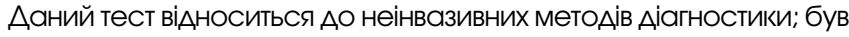
валіАований Аля Аіагностики як фіброзу ( $\geq F 2)$, так і цирозу. В Україні АаниЙ тест використовується з ЄАИною точкою віАсічки (пороговим значенням) Аля виявлення Аорослихпацієнтів з цирозом (METAVIR F4), тобто тих, хто потребує противірусного лікування. У Аорослих (при значеннях >2) тест АОзволяє виявляти третину осіб з цирозом печінки. Використовується точка віАсічки (порогове значення) 2,0; оскільки низьке порогове значення призвоАить Ао великої кількостіхибнопозитивних результатів тестування. Також, імовірно, Аорослі з цирозом печінки не виявлені за Аопомогою тесту APRI при використанні точки віАсічки (порогового значення) 2,0; буАуть виявлені як такі, хто потребує противірусного лікування, завАяाки іншим критеріям (наприк^аА, стійкі аномальні рівні АCТ, а такожАОкази триваючої реплікації ВГВ (АНК НBV $>20000$ MO/M^). APRI розраховується за наступною формулою:

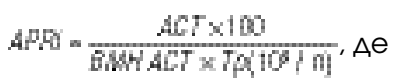

АCT- аспартатамінотрансфераза (в $\mathrm{MO} / \wedge$ );

ВMН ACT - верхня межа норми АСТ в Ааній ^абораторії (в MO/^); Тр - тромбоцити.

\section{ПриклаА розрахунку:}

У пацієнта $A C T=82 \mathrm{MO} / \wedge$ (в ^абораторії, в якій провоАилось обстеження, ВМН АСТ склаАає $40 \mathrm{MO} / \wedge$ ), а кількість тромбоцитів у загальному аналізі крові Аорівнює $90 \times 10^{9} / \wedge$.

При цьому APRI буАе склаАати: $(82 \times 100) /(40 \times 90)=2,28$ Отримане значення >2, що свіАчить на користь цирозу. 
Ао Уніфікованого клінічного протоколу первинної, вторинної (спеціалізованої), третинної (високоспеціалізованої) меАичної Аопомоги «Вірусний гепатит В у Аорослих»

\section{Розрахунок швидкості клубочкової фільтрації нирок}

Розрахункова швиАкість кАубочкової фільтрації (рШКФ) визначається або за формулою Кокрофта-Голта або за формулою MDRD.

\section{Формула Кокрофта-Голта:}

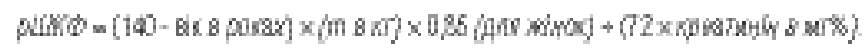

Так, наприк^аА, рШКФ при концентрації креатиніну 125 мкмоль/^ (1 мкмоль/^ = 0,0113 мг\%) буАе склаАати:

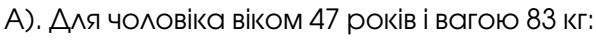
$75,9 \mathrm{M} \wedge / \mathrm{XB} / 1,73 \mathrm{M}^{2}$.

Б). $А \wedge я$ жінки віком 47 років і вагою $83 \mathrm{kг:}$ $64,5 \mathrm{M} \wedge / \mathrm{XB} / 1,73 \mathrm{M}^{2}$.
Формула MDRD:

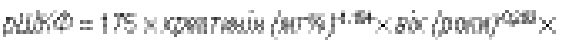

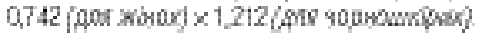

Оцінка ШКФ на основі цих формул може неАооцінювати ступінь ниркової Аисфункції, якщо м' язова маса менше віА вікових і статевих стандартів, як це часто буває у ВІ^-інфікованих осіб.

Так, наприк^аА, рШКФ при концентрації креатиніну 125 мкмоль/^ (1 мкмоль/^ = 0,0113 мг\%) буАе ск^аАати:

А). А^я чоловіка віком 47 років: $53,77 \mathrm{м \wedge} / \mathrm{Xв} / 1,73 \mathrm{M}^{2}$.

Б). $\triangle \wedge$ жінки віком 47 років: $39,89 \mathrm{M} \wedge / \mathrm{XB} / 1,73 \mathrm{~m}^{2}$.

B). $\triangle \wedge я$ темношкірої жінки віком 47 років: $48,35 \mathrm{~m} \wedge / \mathrm{xв} / 1,73 \mathrm{M}^{2}$.

Г). $А \wedge я$ темношкірого чоловіка віком 47 років: 65, $17 \mathrm{M} \wedge / \mathrm{xB} / 1,73 \mathrm{M}^{2}$. 